Jurnal Indonesia Sosial Teknologi:p-ISSN: 2723 - 6609

e-ISSN :2745-5254

Vol. 2, No.12 Desember 2021

\title{
ANALISIS PADA PROSES 3D PRINTER TERHADAP PENGUJIAN TARIK MENGGUNAKAN FILAMEN PLA PRO
}

\author{
Riskullah Dirga Trisaplin', Zaldy Sirwansyah Suzen², Subkhan ${ }^{3}$ \\ Jurusan Teknik Mesin, Politeknik Manufaktur Negeri Bangka Belitung \\ Email: riskullah.dirga@yahoo.com,syahdika99@gmail.com, subilaihan@gmail.com
}

\begin{abstract}
Abstrak
Hadirnya Revolusi Industri 4.0 menyebabkan teknologi di bidang industri manufaktur berkembang sangat pesat, salah satunya mesin Rapid Prototyping dengan teknologi FDM yang merupakan mesin cetak 3 dimensi dengan prinsip pencetakan secara additive manufacturing informasi mengenai sparameter proses yang dapat menghasilkan suatu produk 3D dengan kekuatan tarik secara ideal di Indonesia sangat minim, mengingat informasi tersebut sangat diperlukan dunia industri, sehingga penelitian ini bertujuan untuk mengetahui nilai kekuatan tarik serta parameter proses yang ideal dengan menggunakan filamen PLA PRO Metode yang digunakan pada penelitian ini adalah metode eksperimen faktorial, penelitian ini menggunakan mesin 3D printer Anet Et4, nozzle berukuran $0,4 \mathrm{~mm}$, variasi parameter yang digunakan yaitu 3 level nozzle temperature, 15 infill pattern berdasarkan software Prusaslicer 2.3 dan orientasi sudut pencetakan vertikal $0^{\circ}$. Sehingga menghasilkan 45 kombinasi eksperimen. Hasil dari pengujian tarik tertinggi sebesar 44,2 yang terdapat pada eksperimen nomor 10 infill pattern 3D Honeycomb, Nozzle Temperature $210^{\circ} \mathrm{C}$, sudut pencetakan vertikal $0^{\circ}$. Sedangkan nilai kekuatan tarik terendah terdapat pada eksperimen nomor 43 dengan parameter infill Pattern Archimedean Chord, Nozzle Temperature $220^{\circ} \mathrm{C}$, sudut pencetakan vertikal $0^{\circ}$, dengan nilai kekuatan tarik sebesar $15,7 \mathrm{MPa}$. Sehingga dapat disimpulkan parameter proses tersebut mempengaruhi hasil dari pencetakan produk $3 \mathrm{D}$ printing.
\end{abstract}

Kata kunci: (3D Printer; Rapid Prototyping; FDM; Nozzle Temperature; Infill Pattern)

\section{Abstract}

The presence of the Industrial Revolution 4.0 has caused technology in the manufacturing industry to develop very rapidly, one of which is themachine Rapid Prototyping with FDM technology which is a 3-dimensional printing machine with the principle ofprinting additive manufacturing information on process parameters that can produce a $3 D$ product with ideal tensile strength in Indonesia is very minimal, considering that this information is needed by the industrial world, so this study aims to determine the value of tensile strength and ideal process parameters using PLA PRO filament The method used in this study is the factorial experimental method, this study uses the $3 D$ printer Anet Et4machine. , nozzle measuring $0.4 \mathrm{~mm}$, the parameter variations used are 3levels nozzle temperature, 15 infill patterns based on software Prusaslicer 2.3and $0^{\circ}$ vertical 
printing angle orientation. This results in 45 experimental combinations. The results of the highest tensile test of 44.2 were found in experiment number 10 infill pattern 3D Honeycomb, Nozzle Temperature $210^{\circ} \mathrm{C}$, vertical printing angle of 0. While the lowest tensile strength value is found in experiment number 43 withparameters infill Archimedean Chord Pattern, Nozzle Temperature $220^{\circ} \mathrm{C}$, vertical molding angle of 0 , with a tensile strength value of $15.7 \mathrm{MPa}$. So it can be concluded that these process parameters affect the results of printing 3Dproducts printing.

Keywords: (3D Printer; Rapid Prototyping; FDM; Nozzle Temperature; Infill Pattern)

\section{Pendahuluan}

Hadirnya, Revolusi industri 4.0 (Candra, 2021) membuat dunia industri bersaing sangat ketat, munculnya printer 3D sebagai terobosoan mulai digemari di dunia industri manufaktur indonesia, proses pembuatan prototipe yang umumnya memakan waktu lama bisa dikerjakan dengan singkat (Riza, Budiyantoro, \& Nugroho, 2020), Saat ini sedikit sekali informasi mengenai hasil 3D printing di Indonesia, seperti kekasaran, akurasi, kekuatan tarik, dan lain sebagainya. Agar hasil prototype di buat sesuai dengan harapan maka informasi seperti itu sangat penting untuk di ketahui.

3D Printer adalah teknik Additive Manufacturing (AM) untuk membuat berbagai macam struktur dan geometri kompleks dari data model tiga dimensi (3D) (Saputra, Herianto, \& Pamasaria, 2019). Proses pencetakan terdiri dari lapisan-lapisan bahan yang berhasil dibentuk di atas satu sama lain (Mohamed, Masood, \& Bhowmik, 2015) Sehingga, memungkinkan untuk membuat bentuk apa pun yang sangat sulit dibuat dengan tangan, dan juga telah digunakan di berbagai industri, termasuk kesehatan, sains, pembuatan prototipe, konstruksi, dan biomekanik. (Prasnowo, Findiastuti, \& Utami, 2020) Teknologi 3D Printer yang terkenal salah satunya adalah Fused Deposition Modelling (FDM), FDM telah banyak digunakan dalam teknologi manufaktur aditif yang menyediakan prototipe fungsional dalam berbagai termoplastik karena kemampuannya untuk menghasilkan bagian geometris kompleks dengan rapi dan aman lingkungan. (Mohamed et al., 2015). Material Filamen menjadi bahan utama dalam pembuatan produk 3D Printing yang berfungsi sebagai bahan inti dalam proses pencetakan. Mengacu pada (Grabowik, Kalinowski, Ćwikła, Paprocka, \& Kogut, 2017) ada beberapa jenis filamen yang biasa digunakan pada printer $3 \mathrm{D}$, seperti polyethylene terephthalate glycol (PETG), nylon, polylactic acid (PLA), polycarbonate (PC), dan acrylonitrile butadiene styrene (ABS), dan lain-lain.

Pada Penelitian yang dilakukan oleh (Yao, Deng, Zhang, \& Li, 2019) penulis tersebut meneliti mengenai pengaruh parameter kekuatan tarik sehingga mendapatkan hasil yang optimal pada hasil pencetakan produk 3D Printing dengan menggunakan material filamen PLA. Parameter yang digunakan pada penelitian ini adalah sudut pencetakan dan layer thickness dimana sudut yang digunakan yaitu $0^{\circ}, 15^{\circ}, 30^{\circ}, 45^{\circ}$, $75^{\circ}$, dan $0^{\circ}$ dengan variasi 3 level pada layer thickness. Dari penelitian ini peneliti menarik kesimpulan bahwa kekuatan tarik produk 3D Printing mengalami perubahan 
yang signifikan dimana nilai GAP terbesar berada diantar sudut $0^{\circ}-0^{\circ}$ dengan layer thickness sebesar $0,1 \mathrm{~mm}$. Nilai gap yang terdapat pada sudut $0^{\circ}-0^{\circ}$ dengan layer thickness sebesar 0,1 mm adalah 52,29\%.

Penelitian yang dilakukan oleh (Suzen, 2020) berfokus untuk mengetahui pengaruh infill pattern serta Nozzle Temperature terhadap pengujian kekuatan tarik hasil pencetakan produk 3D Printing dengan menggunakan material filamen PLA+ ESUN. Peneliti melakukan variasi terhadap parameter yang digunakan seperti Nozzle Temperature dengan 3 level suhu yang berbeda yaitu $225^{\circ} \mathrm{C} 205^{\circ} \mathrm{C}$, dan $215^{\circ} \mathrm{C}$, layer thickness dengan ketebalan sebesar $0,2 \mathrm{~mm}$, bed Temperature dengan suhu $60{ }^{\circ} \mathrm{C}$, travel speed dengan kecepatan sebesar $100 \mathrm{~mm} / \mathrm{s}$, Printing speed dengan kecepatan sebesar 50 $\mathrm{mm} / \mathrm{s}$ dan 13 infill pattern, adapun infill pattern yang digunakan yaitu cross 3D, cubic, concentric, grid, gyroid, lines, octet, quarter cubic, triangles, tri hexagon, cubic division, dan zig zag, dalam penelitiannya metode yang digunakan yaitu metode faktorial, faktor yang satu dikalikan dengan faktor yang lainnya sehingga menghasilkan 39 spesimen uji. Dari penelitian ini didapatkan hasil bahwa kekuatan tarik filamen PLA+ ESUN dipengaruhi oleh Nozzle Temperature dan infill pattern dengan nilai kekuatan tarik tertinggi sebesar 43,20 MPa dimana parameter yang digunakan yaitu infill patern dengan variasi concentric dengan suhu yang digunakan pada Nozzle sebesar $215^{\circ} \mathrm{C}$.

Dalam studi literatur, berbagai metode dapat digunakan untuk menentukan kualitas suatu produk. Metode yang paling umum adalah pengujian tarik terhadap uji spesimen, yang menggunakan parameter proses seperti sudut pencetakan, pola pengisian, lebar ekstrusi, dan suhu nozzle. Penulis akan melakukan penelitian untuk mengetahui pengaruh pola infill dan Temperatur Nozzle terhadap kekuatan tarik produk 3D Printing dengan arah sudut pencetakan vertikal $0^{\circ}$ menggunakan filamen polylactic acid PRO (PLA PRO) untuk mengetahui nilai kekuuatan tarik.

\section{Metode Penelitian}

Proses pencetakan spesimen uji dilakukan menggunakan mesin 3D printer model PRUSA merk Anet Et4, printing area X, Y, Z sebesar $220 \mathrm{~mm}$ x $220 \mathrm{~mm}$ x 250 mm, menggunakan ukuran nozzle $0,4 \mathrm{~mm}$, material filamen PLA PRO merek R3D MAKER dengan diameter $1,75 \mathrm{~mm}$, serta menggunakan mesin uji tarik merek Zwick Roell Z020 type Xforce K.

Metode pada penelitian ini menggunakan metode eksperimen faktorial, parameter yang digunakan ialah nozzle temperature dan infill pattern, untuk menentukan kombinasi parameter maka dilakukan perkalian antara 3 level suhu nozzle dengan 15 tipe infill, sehingga menghasilkan 45 kombinasi pencetakan yang ditunjukan pada tabel 1 . 
Riskullah Dirga Trisaplin ${ }^{1}$, Zaldy Sirwansyah $\operatorname{Suzen}^{2}$, Subkhan ${ }^{3}$

Tabel 1 Kombinasi Parameter Pencetakan

\begin{tabular}{|c|c|c|c|c|c|c|c|c|}
\hline $\begin{array}{l}\text { Exp. } \\
\text { No }\end{array}$ & $\begin{array}{c}\text { Nozzle } \\
\text { temperature } \\
\left({ }^{\circ} \mathrm{C}\right)\end{array}$ & $\begin{array}{c}\text { Layer } \\
\text { thickness } \\
(\mathrm{mm})\end{array}$ & $\begin{array}{c}\text { Bed } \\
\text { temperature } \\
\left({ }^{\circ} \mathrm{C}\right)\end{array}$ & $\begin{array}{l}\text { Travel } \\
\text { Speed } \\
(\mathrm{mm} / \mathrm{s})\end{array}$ & $\begin{array}{c}\text { Printing } \\
\text { Speed } \\
(\mathrm{mm} / \mathrm{s})\end{array}$ & $\begin{array}{c}\text { Orient } \\
\text { asi } \\
\text { vertikal } \\
\left({ }^{\circ}\right)\end{array}$ & $\begin{array}{c}\text { Infill } \\
\text { density } \\
(\%)\end{array}$ & Infill patern \\
\hline 1 & 210 & 0.2 & 60 & 100 & 40 & 0 & 80 & Rectilinear \\
\hline 2 & 210 & 0.2 & 60 & 100 & 40 & 0 & 80 & $\begin{array}{c}\text { Aligned } \\
\text { Rectilinear }\end{array}$ \\
\hline 3 & 210 & 0.2 & 60 & 100 & 40 & 0 & 80 & Grid \\
\hline 4 & 210 & 0.2 & 60 & 100 & 40 & 0 & 80 & Triangles \\
\hline 5 & 210 & 0.2 & 60 & 100 & 40 & 0 & 80 & Stars \\
\hline 6 & 210 & 0.2 & 60 & 100 & 40 & 0 & 80 & Cubic \\
\hline 7 & 210 & 0.2 & 60 & 100 & 40 & 0 & 80 & Line \\
\hline 8 & 210 & 0.2 & 60 & 100 & 40 & 0 & 80 & Concentric \\
\hline 9 & 210 & 0.2 & 60 & 100 & 40 & 0 & 80 & Honeycomb \\
\hline 10 & 210 & 0.2 & 60 & 100 & 40 & 0 & 80 & 3D Honeycomb \\
\hline 11 & 210 & 0.2 & 60 & 100 & 40 & 0 & 80 & Gyroid \\
\hline 12 & 210 & 0.2 & 60 & 100 & 40 & 0 & 80 & Hilbert Curve \\
\hline 13 & 210 & 0.2 & 60 & 100 & 40 & 0 & 80 & $\begin{array}{l}\text { Archimedean } \\
\text { Chords }\end{array}$ \\
\hline 14 & 210 & 0.2 & 60 & 100 & 40 & 0 & 80 & Octagram Spiral \\
\hline 15 & 210 & 0.2 & 60 & 100 & 40 & 0 & 80 & Adaptive Cubic \\
\hline 16 & 220 & 0.2 & 60 & 100 & 40 & 0 & 80 & Rectilinear \\
\hline 17 & 220 & 0.2 & 60 & 100 & 40 & 0 & 80 & $\begin{array}{c}\text { Aligned } \\
\text { Rectilinear }\end{array}$ \\
\hline 18 & 220 & 0.2 & 60 & 100 & 40 & 0 & 80 & Grid \\
\hline 19 & 220 & 0.2 & 60 & 100 & 40 & 0 & 80 & Triangles \\
\hline 20 & 220 & 0.2 & 60 & 100 & 40 & 0 & 80 & Stars \\
\hline 21 & 220 & 0.2 & 60 & 100 & 40 & 0 & 80 & Cubic \\
\hline 22 & 220 & 0.2 & 60 & 100 & 40 & 0 & 80 & Line \\
\hline 23 & 220 & 0.2 & 60 & 100 & 40 & 0 & 80 & Concentric \\
\hline 24 & 220 & 0.2 & 60 & 100 & 40 & 0 & 80 & Honeycomb \\
\hline 25 & 220 & 0.2 & 60 & 100 & 40 & 0 & 80 & 3D Honeycomb \\
\hline 26 & 220 & 0.2 & 60 & 100 & 40 & 0 & 80 & Gyroid \\
\hline 27 & 220 & 0.2 & 60 & 100 & 40 & 0 & 80 & Hilbert Curve \\
\hline 28 & 220 & 0.2 & 60 & 100 & 40 & 0 & 80 & $\begin{array}{l}\text { Archimedean } \\
\text { Chords }\end{array}$ \\
\hline 29 & 220 & 0.2 & 60 & 100 & 40 & 0 & 80 & Octagram Spiral \\
\hline 30 & 220 & 0.2 & 60 & 100 & 40 & 0 & 80 & Adaptive Cubic \\
\hline 31 & 230 & 0.2 & 60 & 100 & 40 & 0 & 80 & Rectilinear \\
\hline 32 & 230 & 0.2 & 60 & 100 & 40 & 0 & 80 & $\begin{array}{c}\text { Aligned } \\
\text { Rectilinear }\end{array}$ \\
\hline 33 & 230 & 0.2 & 60 & 100 & 40 & 0 & 80 & Grid \\
\hline 34 & 230 & 0.2 & 60 & 100 & 40 & 0 & 80 & Triangles \\
\hline 35 & 230 & 0.2 & 60 & 100 & 40 & 0 & 80 & Stars \\
\hline 36 & 230 & 0.2 & 60 & 100 & 40 & 0 & 80 & Cubic \\
\hline 37 & 230 & 0.2 & 60 & 100 & 40 & 0 & 80 & Line \\
\hline 38 & 230 & 0.2 & 60 & 100 & 40 & 0 & 80 & Concentric \\
\hline 39 & 230 & 0.2 & 60 & 100 & 40 & 0 & 80 & Honeycomb \\
\hline 40 & 230 & 0.2 & 60 & 100 & 40 & 0 & 80 & 3D Honeycomb \\
\hline 41 & 230 & 0.2 & 60 & 100 & 40 & 0 & 80 & Gyroid \\
\hline 42 & 230 & 0.2 & 60 & 100 & 40 & 0 & 80 & Hilbert Curve \\
\hline 43 & 230 & 0.2 & 60 & 100 & 40 & 0 & 80 & $\begin{array}{l}\text { Archimedean } \\
\text { Chords }\end{array}$ \\
\hline
\end{tabular}




\begin{tabular}{ccccccccc}
\hline $\begin{array}{c}\text { Exp. } \\
\text { No }\end{array}$ & $\begin{array}{c}\text { Nozzle } \\
\text { temperature } \\
\left({ }^{\circ} \boldsymbol{C}\right)\end{array}$ & $\begin{array}{c}\text { Layer } \\
\text { thickness } \\
(\mathbf{m m})\end{array}$ & $\begin{array}{c}\text { Bed } \\
\text { temperature } \\
\left({ }^{\circ} \boldsymbol{C}\right)\end{array}$ & $\begin{array}{c}\text { Travel } \\
\text { Speed } \\
(\mathbf{m m} / \mathbf{s})\end{array}$ & $\begin{array}{c}\text { Printing } \\
\text { Speed } \\
(\mathbf{m m} / \mathbf{s})\end{array}$ & $\begin{array}{c}\text { Orient } \\
\text { asi } \\
\text { vertikal } \\
\left({ }^{\circ}\right)\end{array}$ & $\begin{array}{c}\text { Infill } \\
\text { density } \\
(\%)\end{array}$ & Infill patern \\
\hline 44 & 230 & 0.2 & 60 & 100 & 40 & 0 & 80 & Octagram Spiral \\
\hline 45 & 230 & 0.2 & 60 & 100 & 40 & 0 & 80 & Adaptive Cubic \\
\hline
\end{tabular}

Pada penelitian ini untuk menentukan parameter proses yang digunakan diawali dengan studi literatur dan spesifikasi filamen PLA PRO, kemudian proses pembuatan model spesimen dilakukan dengan bantuan software gambar 3D dengan acuan ASTM D638-14 Tipe 4 sebagai dasarnya, file gambar disimpan dalam format STL (*.stl). Selanjutnya masuk ke tahap slicing dalam penelitian ini menggunakan PrusaSlicer 2.3 yang berfungsi untuk menghasilkan perintah pemrograman atau $G$-code, Proses Slicing ditunjukan pada gambar 1.

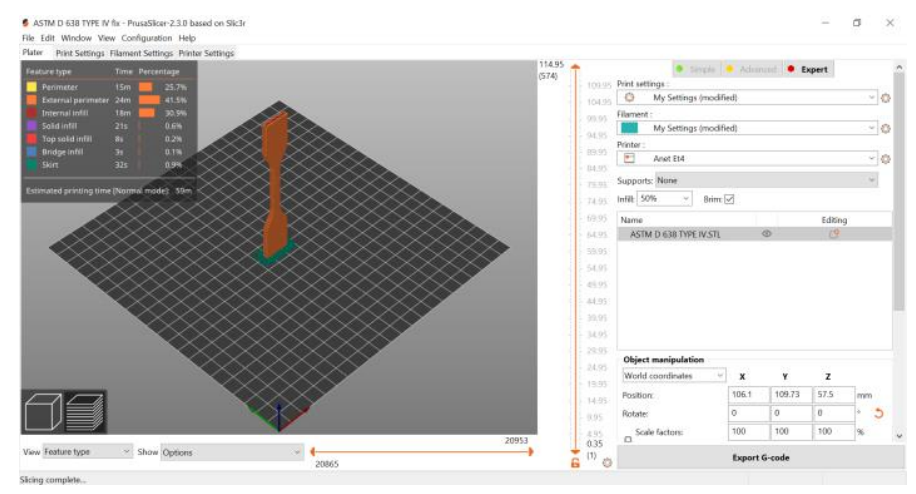

Gambar 1 Proses Slicing

Selanjutnya tahap persiapan penelitian seperti memasang filamen, melakukan proses kalibrasi mesin 3D printer untuk menghindari kemiringan pada bed, memasukan MicroSD yang berisi G-code ke dalam mesin, serta melakukan pengaturan terhadap nozzle temperature dan bed temperature. Setelah proses persiapan penelitian selesai dilanjutkan dengan melakukan pencetakan spesimen uji sebanyak 45 spesimen sesuai dengan kombinasi parameter pencetakan yang telah ditentukan. Proses pencetakan dapat dilihat pada gambar 2 


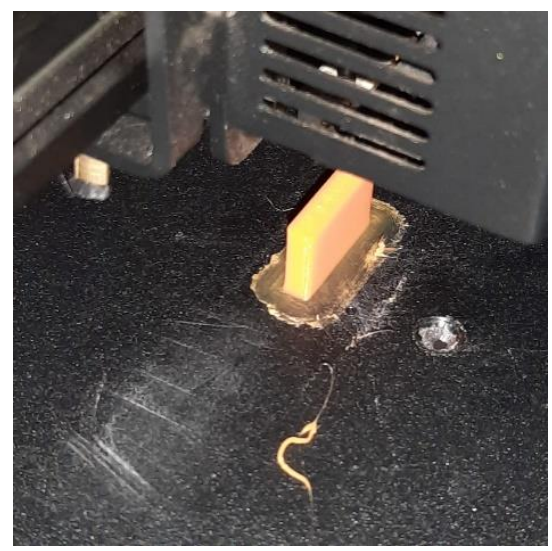

Gambar 2 Proses Pencetakan Spesimen uji

Setelah proses pencetakan spesimen uji selesai dilaksanakan, kemudian dilakukan proses pengujian tarik untuk mengetahui nilai kekuatan tarik pada spesimen uji. Pada penelitian ini pengujian tarik menggunakan mesin uji tarik merek Zwick Roell Z020 type Xforce K.

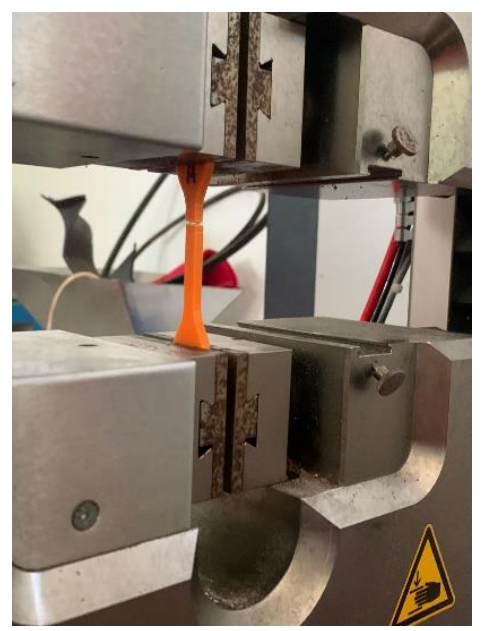

Gambar 3 Proses Pengujian Tarik

\section{Hasil dan Pembahasan \\ Hasil Uji Tarik}

Setelah dilaksanakannya proses perlakuan uji tarik menggunakan mesin Zwick Roell Z020 tipe Xforce K pada spesimen uji berstandar ASTM D638-14 Tipe IV berbahan material PLA PRO, maka didapatlah hasil yang bervariasi pada setiap spesimen dengan parameter bebas seperti Nozzle temperature, 15 tipe Infill Pattern serta sudut orientasi pencetakan. Hasil nilai kuat tarik dapat dilihat pada tabel 2. 
Tabel 2 Hasil Uji Tarik

\begin{tabular}{|c|c|c|c|c|c|c|c|c|c|}
\hline $\begin{array}{l}\text { Exp. } \\
\text { No }\end{array}$ & $\begin{array}{c}\text { Nozzle } \\
\text { temperature } \\
\left({ }^{\circ} \mathrm{C}\right)\end{array}$ & $\begin{array}{c}\text { Layer } \\
\text { thickness } \\
(\mathrm{mm})\end{array}$ & $\begin{array}{c}\text { Bed } \\
\text { temperature } \\
\left({ }^{\circ} \mathrm{C}\right)\end{array}$ & $\begin{array}{l}\text { Travel } \\
\text { Speed } \\
(\mathrm{mm} / \mathrm{s})\end{array}$ & $\begin{array}{c}\text { Printing } \\
\text { Speed } \\
(\mathrm{mm} / \mathrm{s})\end{array}$ & $\begin{array}{c}\text { Orientasi } \\
\text { vertikal } \\
\left(^{\circ}\right)\end{array}$ & $\begin{array}{c}\text { Infill } \\
\text { densi } \\
\text { ty } \\
(\%)\end{array}$ & Infill patern & $\begin{array}{c}\text { Hasil } \\
\text { pengujia } \\
n\end{array}$ \\
\hline 1 & 210 & 0.2 & 60 & 100 & 40 & 0 & 80 & Rectilinear & 23.8 \\
\hline 2 & 210 & 0.2 & 60 & 100 & 40 & 0 & 80 & $\begin{array}{c}\text { Aligned } \\
\text { Rectilinear }\end{array}$ & 31.0 \\
\hline 3 & 210 & 0.2 & 60 & 100 & 40 & 0 & 80 & Grid & 26.2 \\
\hline 4 & 210 & 0.2 & 60 & 100 & 40 & 0 & 80 & Triangles & 25.2 \\
\hline 5 & 210 & 0.2 & 60 & 100 & 40 & 0 & 80 & Stars & 24.7 \\
\hline 6 & 210 & 0.2 & 60 & 100 & 40 & 0 & 80 & Cubic & 20.8 \\
\hline 7 & 210 & 0.2 & 60 & 100 & 40 & 0 & 80 & Line & 27.0 \\
\hline 8 & 210 & 0.2 & 60 & 100 & 40 & 0 & 80 & Concentric & 20.8 \\
\hline 9 & 210 & 0.2 & 60 & 100 & 40 & 0 & 80 & Honeycomb & 27.1 \\
\hline 10 & 210 & 0.2 & 60 & 100 & 40 & 0 & 80 & $\begin{array}{c}\text { 3D } \\
\text { Honeycomb }\end{array}$ & 44.2 \\
\hline 11 & 210 & 0.2 & 60 & 100 & 40 & 0 & 80 & Gyroid & 24.4 \\
\hline 12 & 210 & 0.2 & 60 & 100 & 40 & 0 & 80 & $\begin{array}{l}\text { Hilbert } \\
\text { Curve }\end{array}$ & 16.3 \\
\hline 13 & 210 & 0.2 & 60 & 100 & 40 & 0 & 80 & $\begin{array}{c}\text { Archimedea } \\
\text { n Chords }\end{array}$ & 16.0 \\
\hline 14 & 210 & 0.2 & 60 & 100 & 40 & 0 & 80 & $\begin{array}{c}\text { Octagram } \\
\text { Spiral }\end{array}$ & 21.0 \\
\hline 15 & 210 & 0.2 & 60 & 100 & 40 & 0 & 80 & $\begin{array}{l}\text { Adaptive } \\
\text { Cubic }\end{array}$ & 20.3 \\
\hline 16 & 220 & 0.2 & 60 & 100 & 40 & 0 & 80 & Rectilinear & 26.8 \\
\hline 17 & 220 & 0.2 & 60 & 100 & 40 & 0 & 80 & $\begin{array}{c}\text { Aligned } \\
\text { Rectilinear }\end{array}$ & 26.3 \\
\hline 18 & 220 & 0.2 & 60 & 100 & 40 & 0 & 80 & Grid & 29.8 \\
\hline 19 & 220 & 0.2 & 60 & 100 & 40 & 0 & 80 & Triangles & 26.2 \\
\hline 20 & 220 & 0.2 & 60 & 100 & 40 & 0 & 80 & Stars & 28.7 \\
\hline 21 & 220 & 0.2 & 60 & 100 & 40 & 0 & 80 & Cubic & 24.3 \\
\hline 22 & 220 & 0.2 & 60 & 100 & 40 & 0 & 80 & Line & 30.5 \\
\hline 23 & 220 & 0.2 & 60 & 100 & 40 & 0 & 80 & Concentric & 22.7 \\
\hline 24 & 220 & 0.2 & 60 & 100 & 40 & 0 & 80 & Honeycomb & 30.6 \\
\hline 25 & 220 & 0.2 & 60 & 100 & 40 & 0 & 80 & $\begin{array}{c}\text { 3D } \\
\text { Honeycomb }\end{array}$ & 38.1 \\
\hline 26 & 220 & 0.2 & 60 & 100 & 40 & 0 & 80 & Gyroid & 22.7 \\
\hline 27 & 220 & 0.2 & 60 & 100 & 40 & 0 & 80 & $\begin{array}{l}\text { Hilbert } \\
\text { Curve }\end{array}$ & 18.7 \\
\hline
\end{tabular}


Riskullah Dirga Trisaplin ${ }^{1}$, Zaldy Sirwansyah Suzen², Subkhan ${ }^{3}$

\begin{tabular}{|c|c|c|c|c|c|c|c|c|c|}
\hline $\begin{array}{l}\operatorname{Exp} . \\
\text { No }\end{array}$ & $\begin{array}{c}\text { Nozzle } \\
\text { temperature } \\
\left({ }^{\circ} \mathrm{C}\right)\end{array}$ & $\begin{array}{c}\text { Layer } \\
\text { thickness } \\
(\mathrm{mm})\end{array}$ & $\begin{array}{c}\text { Bed } \\
\text { temperature } \\
\left.\quad{ }^{\circ} \mathrm{C}\right)\end{array}$ & $\begin{array}{l}\text { Travel } \\
\text { Speed } \\
(\mathrm{mm} / \mathrm{s})\end{array}$ & $\begin{array}{c}\text { Printing } \\
\text { Speed } \\
(\mathrm{mm} / \mathrm{s})\end{array}$ & $\begin{array}{c}\text { Orientasi } \\
\text { vertikal } \\
\left({ }^{\circ}\right)\end{array}$ & $\begin{array}{c}\text { Infill } \\
\text { densi } \\
\text { ty } \\
(\%)\end{array}$ & Infill patern & $\begin{array}{c}\text { Hasil } \\
\text { pengujia } \\
\mathbf{n}\end{array}$ \\
\hline 28 & 220 & 0.2 & 60 & 100 & 40 & 0 & 80 & $\begin{array}{l}\text { Archimedea } \\
\text { n Chords }\end{array}$ & 16.0 \\
\hline 29 & 220 & 0.2 & 60 & 100 & 40 & 0 & 80 & $\begin{array}{c}\text { Octagram } \\
\text { Spiral }\end{array}$ & 17.9 \\
\hline 30 & 220 & 0.2 & 60 & 100 & 40 & 0 & 80 & $\begin{array}{l}\text { Adaptive } \\
\text { Cubic }\end{array}$ & 21.8 \\
\hline 31 & 230 & 0.2 & 60 & 100 & 40 & 0 & 80 & Rectilinear & 27.9 \\
\hline 32 & 230 & 0.2 & 60 & 100 & 40 & 0 & 80 & $\begin{array}{c}\text { Aligned } \\
\text { Rectilinear }\end{array}$ & 21.8 \\
\hline 33 & 230 & 0.2 & 60 & 100 & 40 & 0 & 80 & Grid & 29.2 \\
\hline 34 & 230 & 0.2 & 60 & 100 & 40 & 0 & 80 & Triangles & 24.2 \\
\hline 35 & 230 & 0.2 & 60 & 100 & 40 & 0 & 80 & Stars & 27.5 \\
\hline 36 & 230 & 0.2 & 60 & 100 & 40 & 0 & 80 & Cubic & 22.5 \\
\hline 37 & 230 & 0.2 & 60 & 100 & 40 & 0 & 80 & Line & 32.7 \\
\hline 38 & 230 & 0.2 & 60 & 100 & 40 & 0 & 80 & Concentric & 25.0 \\
\hline 39 & 230 & 0.2 & 60 & 100 & 40 & 0 & 80 & Honeycomb & 28.8 \\
\hline 40 & 230 & 0.2 & 60 & 100 & 40 & 0 & 80 & $\begin{array}{c}\text { 3D } \\
\text { Honeycomb }\end{array}$ & 39.7 \\
\hline 41 & 230 & 0.2 & 60 & 100 & 40 & 0 & 80 & Gyroid & 21.1 \\
\hline 42 & 230 & 0.2 & 60 & 100 & 40 & 0 & 80 & $\begin{array}{l}\text { Hilbert } \\
\text { Curve }\end{array}$ & 26.9 \\
\hline 43 & 230 & 0.2 & 60 & 100 & 40 & 0 & 80 & $\begin{array}{l}\text { Archimedea } \\
\text { n Chords }\end{array}$ & 15.7 \\
\hline 44 & 230 & 0.2 & 60 & 100 & 40 & 0 & 80 & $\begin{array}{l}\text { Octagram } \\
\text { Spiral }\end{array}$ & 18.5 \\
\hline 45 & 230 & 0.2 & 60 & 100 & 40 & 0 & 80 & $\begin{array}{l}\text { Adaptive } \\
\text { Cubic }\end{array}$ & 18.9 \\
\hline
\end{tabular}

\section{Analisa Hasil Uji Tarik}

Setelah melaksanakan pengujian tarik terhadap spesimen cetak, diperoleh hasil nilai kekuatan tarik yang terdapat pada tabel 2, kemudian data tersebut diolah ke dalam grafik untuk mempermudah proses analisa, hasil analisa akan menunjukan nilai kekuatan tarik tertinggi dan terendah, serta pengaruh parameter proses terhadap hasil pengujian tarik spesimen uji (Hasan, Istana, \& Mahbub, 2014). Grafik hasil uji tarik terdapat pada gambar 4. 


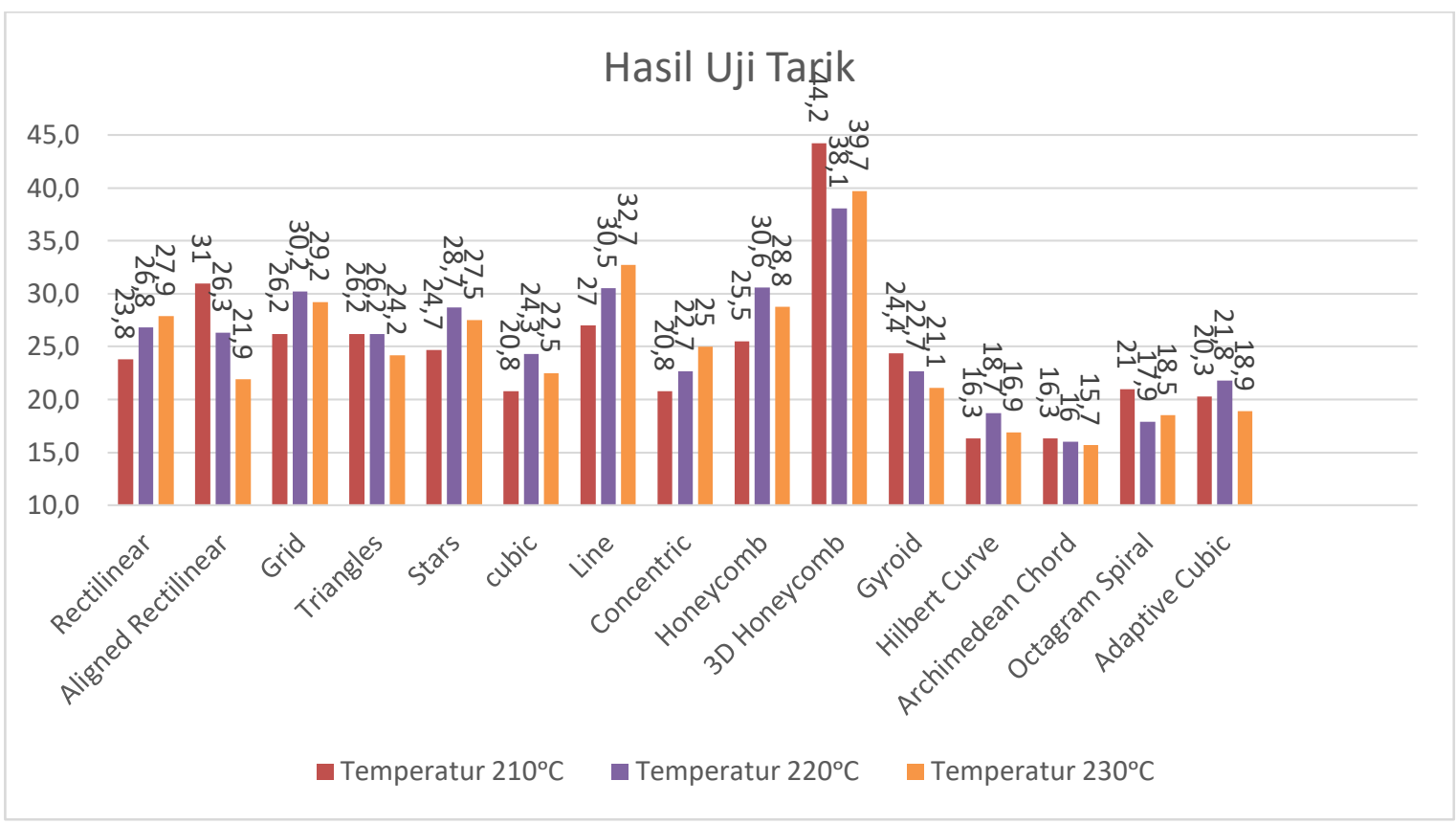

\section{Gambar 4 Grafik Uji Tarik}

Berdasarkan grafik diatas, menyatakan bahwa terdapat perbedaan nilai kekuatan tarik pada infill pattern, terhadap varians nozzle temperature (Fimansyah, 2017). Secara keseluruhan nilai kekuatan tarik tertinggi ditempati oleh tipe infill yang sama yaitu 3D Honeycomb, Pada suhu $210^{\circ} \mathrm{C}$ nilai kekuatan tarik tertinggi sebesar 44,2 Mpa, sedangkan nilai kekuatan tarik terendah terdapat pada tipe infill hilbert curve dan archimedean chord sebesar $16,3 \mathrm{Mpa}$. Pada suhu $220^{\circ} \mathrm{C}$ nilai kekuatan tarik tertinggi sebesar 38,1, nilai kekuatan tarik terendah terdapat tipe infill archimedean chord sebesar $16 \mathrm{Mpa}$, Pada suhu $230^{\circ} \mathrm{C}$ nilai kekuatan tarik tertinggi sebesar 39,7 Mpa, dan nilai kekuatan tarik terendah terdapat pada tipe infill yang sama dengan suhu $220^{\circ} \mathrm{C}$ sebesar 15,7 Mpa.

Grafik juga menunjukan bahwa infill pattern rectilinear, line, dan concentric semakin besar suhu pencetakan maka nilai kekuatan tarik akan meningkat, pada infill pattern aligned rectilinear, gyroid, dan archimedean chord semakin besar suhu pencetakan maka kekuatan tarik akan menurun.

Atas analisa yang telah dilakukan menunjukan bahwa parameter infill pattern dan nozzle temperature mempengaruhi hasil nilai kekuatan tarik spesimen uji menggunakan filamen PLA PRO.

\section{Kesimpulan}

Berdasarkan analisa dan pengolahan data terhadap nilai kekuatan tarik spesimen uji, maka dapat disimpulkan bahwa nilai kekuatan tarik tertinggi terdapat pada spesimen nomor 10 infill pattern $3 D$ Honeycomb, nozzle temperature $210^{\circ} \mathrm{C}$ sebesar $44,2 \mathrm{Mpa}$, sedangkan nilai kekuatan tarik terendah terdapat pada spesimen nomor 43 infill pattern archimedean chord, nozzle temperature $230^{\circ} \mathrm{C}$, parameter proses (nozzle temperature 
Riskullah Dirga Trisaplin ${ }^{1}$, Zaldy Sirwansyah Suzen ${ }^{2}$, Subkhan $^{3}$

dan infill pattern) mempengaruhi hasil pencetakan produk 3D printing dengan orientasi sudut pencetakan $0^{\circ}$. 


\section{Bibliografi}

Candra, Angga Dwi. (2021). Analisislean Manufacturing Guna Peningkatan Profit Ukm Sari Kelapa. Universitas Muhammadiyah Gresik.

Fimansyah, Andrian. (2017). Rancang Bangun Prosthesis Bagian Telapak Tangan untuk Rehabilitasi Penderita Kusta dengan Konsep Personal Fit, Breathable, dan Light Movement. Institut Teknologi Sepuluh Nopember.

Grabowik, Cezary, Kalinowski, Krzysztof, Ćwikła, Grzegorz, Paprocka, Iwona, \& Kogut, Pawel. (2017). Tensile tests of specimens made of selected group of the filament materials manufactured with FDM method. MATEC Web of Conferences, 112, 4017. EDP Sciences.

Hasan, Indra, Istana, Budi, \& Mahbub, Aulia. (2014). Analisa Kekuatan Tarik Serat Sabut Kelapa dengan Orientasi Serat Pendek Acak yang Dimanfaatkan sebagai Alternatif Dudukan Kaca Spion Kendaraan.

Mohamed, Omar A., Masood, Syed H., \& Bhowmik, Jahar L. (2015). Optimization of fused deposition modeling process parameters: a review of current research and future prospects. Advances in Manufacturing, 3(1), 42-53.

Prasnowo, M. Adhi, Findiastuti, Weny, \& Utami, Issa Dyah. (2020). Ergonomi Dalam Perancangan Dan Pengembangan Produk Alat Potong Sol Sandal. SCOPINDO MEDIA PUSTAKA.

Riza, Eduar Iqbal, Budiyantoro, Cahyo, \& Nugroho, Aris Widyo. (2020). Peningkatan Kekuatan Lentur Produk 3d Printing Berbahan Petg Dengan Optimasi Parameter Proses Menggunakan Metode Taguchi. Media Mesin: Majalah Teknik Mesin, 21(2), 66-75.

Saputra, Tri Hannanto, Herianto, H., \& Pamasaria, Herda Agus. (2019). Analisa Pengaruh Pemilihan Komponen terhadap Ketelitian Dimensi dan Kualitas Permukaan Produk pada Mesin 3D Printing Jenis FDM (Fused Deposition Modelling). IENACO (Industrial Engineering National Conference) 72019.

Suzen, Z. S. (2020). Pengaruh Tipe Infill dan Temperatur Nozzle terhadap Kekuatan Tarik Produk 3D Printing Filamen Plat Esun. Manutech: Jurnal Teknologi Manufaktur, 12(02), 73-80.

Yao, Tianyun, Deng, Zichen, Zhang, Kai, \& Li, Shiman. (2019). A method to predict the ultimate tensile strength of 3D printing polylactic acid (PLA) materials with different printing orientations. Composites Part B: Engineering, 163, 393-402. 